\title{
Nuclear activity in Apis mellifera L. (Hymenoptera, Apidae) queen ovary cells demonstrated by silver nitrate impregnation and ultrastructure
}

\author{
Cruz-Landim, $C$. ${ }^{\text {a* }}$ and Patrício, $K$. $^{\mathrm{b}}$ \\ aDepartamento de Biologia, Instituto de Biociências de Rio Claro, Universidade Estadual Paulista - UNESP, \\ Av. 24 A, 1515, CEP13506-900, Rio Claro, SP, Brazil \\ 'Departamento de Zootecnia, Laboratório de Biotecnologia, Escola Superior de Agricultura "Luiz de Queiroz"- ESALQ, \\ Universidade de São Paulo - USP, Av. Pádua Dias, 11, CP 9, CEP 13418-900, Piracicaba, SP, Brazil \\ *e-mail: cclandim@rc.unesp.br \\ Received March 27, 2009 - Accepted June 15, 2009 - Distributed November 30, 2010
}

(With 3 figures)

\begin{abstract}
The present paper shows through conventional light microscopy, silver nitrate impregnation and Transmission Electron Microscopy, the changes in nuclear activity that occurs in the ovary cells during vitellogenesis of Apis mellifera (Linnaeus, 1758). The material impregnated by silver nitrate was detected in nurse cells, oocyte germinal vesicle and follicular cells, whose amounts are greater in phases corresponding to ovarian cells more intense activity. The silver impregnation permitted to demonstrate that the oocyte germinal vesicle synthezises ribonucleoproteins (RNP) during the beginning of the vitellogenesis. The ultrastructure show nucleolar-like material corresponding to nuclear sites impregnated by silver.
\end{abstract}

Keyworks: nucleolar, ovary, RNP, vitellogenesis.

\section{Atividade nuclear em células do ovário de rainha de Apis mellifera L. (Hymenoptera, Apidae) demonstrada por impregnação com nitrato de prata e ultraestrutura}

\begin{abstract}
Resumo
Este estudo mostra, por meio de microscopia convencional, impregnação por nitrato de prata e microscopia eletrônica de transmissão, as mudanças que ocorrem na atividade nuclear de células do ovário durante a vitelogênese de Apis mellifera (Linnaeus, 1758). Material impregnado por nitrato de prata foi detectado no núcleo de células nutridoras, na vesícula germinal do ovócito e no núcleo das células foliculares. As maiores quantidades de material impregnado pela prata foram observadas durante as fases de maior atividade dessas estruturas. A impregnação por prata permitiu demonstrar que a vesícula germinal sintetiza ribonucleoproteínas (RNP) durante o início da vitelogênese. A ultraestrutura mostrou que o material impregnado apresenta características morfológicas de nucléolos.
\end{abstract}

Palavras-chave: nucléolos, ovário, RNP, vitelogênese.

\section{Introduction}

In polytrophic meroistic ovaries, such as the ovary of bees, each ovarian follicle is constituted by one or several nurse cells that accompany the oocytes in the vitellarium. Usually the follicles become divided into oocytic and nurse chambers, both surrounded by a layer of follicular cells. As the oocyte develops, the nuclei of the nurse cells change their activity pattern becoming very active and probably becoming polyploid. On the other hand, the nucleus of the oocyte, or germinal vesicle, is assumed to be inactive, and in the follicular cells there are variations in nuclear activity.

The technique of Ag-NOR (silver - nucleolar organiser region), widely used in cytogenetics, was originally used by
Goodpasture and Boom (1975) in order to detect nucleolar organiser regions (NORs) in chromosomes and nucleoli in interphase nuclei, thus providing a visualisation of their functional state. Although there is a vast scientific literature concerning the use of silver impregnation, the mechanism of its cytochemical action remains unknown. According to Schwarzacher et al. (1978), in the case of the utilisation of silver to evidence NORs, the impregnation is due to non-histonic proteins that accumulate around or at the nucleoli, which preferentially capture the silver. Their conclusions were based upon several indirect proofs, such as the amount of non-histonic proteins and the digestion by RNAse. Other authors attributed the evidencing of the 
NORs by silver nitrate to proteins associated to the newly transcribed rRNA (Howell and Hsu, 1979). Lischwe et al. (1979, 1981), among others, attributed the specificity of this procedure for nucleolus, to the proteins nucleoline (C23) and numatrine (B23) present in that organelle.

The study of man-rat somatic cells hybrids indicates that only the regions of the chromosomes that produce rRNA are impregnated by the silver, and the application of this technique on the chromosomes of cricket oocytes led to the same conclusion, suggesting that the silver binds to the proteins that associate rapidly to the rRNA after its transcription (Bicudo et al., 1992). The silver impregnation, therefore, may be a tool for detecting locals of rRNA synthesis.

In the present work, light microscopy preparations stained with hematoxylin and eosin, silver impregnated, and Transmission Electron Microscopy (TEM) were used in order to evaluate the functional state of the nuclei of each ovarian cells follicle in queens of Apis mellifera (Linnaeus, 1758), throughout the developmental progress of the vitellogenesis.

\section{Material and Methods}

\subsection{Bees}

Laying queens of $A$. mellifera were obtained from colonies kept at the Bioterio of the Bioscience Institute of the UNESP, Campus, at Rio Claro - São Paulo State, Brazil.

\subsection{Preparation of histological slides}

Ovaries dissected from the queens were fixed in $4 \%$ paraformaldehyde; in $0.1 \mathrm{M}$, pH 7.4 phosphate buffer during 24 hours. The material was then washed in the buffer and dehydrated in a standard ethanol series $(70,80,90$ and 95\%), 15 minutes in each bath and transferred to JB-4 (Polyscience) or Leica historesin for embedding and blockage according to the manufacturer's instructions.

After polymerisation, the pieces were sectioned at $3 \mu \mathrm{m}$ thickness. The sections put on glass slides, once dried, were stained with Harris Hematoxylin and mounted in Permount.

\subsection{Silver nitrate impregnation}

Ovary histological sections were placed in a wet chamber and, over the sections, a drop of revealing solution ( $1 \mathrm{~g}$ of gelatin in $500 \mathrm{~mL}$ of deionised water containing $0.5 \mathrm{~mL}$ of formic acid) and two drops of $50 \%$ silver nitrate were deposited and left to react for 15 minutes.

After this step, a coverslide was placed over the material, which was left at $60^{\circ} \mathrm{C}$ for approximately 10 minutes, or until the revealing solution presented a caramel or brown coloration. The material was briefly washed in tap water in order to remove the coverslide and the excess of silver.

The slides were placed on a slide rack to dry, clarified in xylol, and mounted in Permount.

\subsection{Transmission Electron Microscopy (TEM)}

The ovaries were fixed in a mixture of $2 \%$ glutaraldehyde and $4 \%$ paraformaldehyde in $0.1 \mathrm{M}, \mathrm{pH} 7.4$ sodium cacodylate buffer for 2 hours at $4{ }^{\circ} \mathrm{C}$. Once fixed, the material was washed twice in the buffer, for 15 minutes each. The ovaries were post-fixed in $1 \%$ osmium tetroxide in the same buffer during 2 hours and again washed twice in the buffer.The fixed ovaries were contrasted in $2 \%$ uranyl acetate in $10 \%$ alcohol during 6 hours and then dehydrated in a standard acetone series $(70,90$, and $95 \%$, five minutes each and then three changes of $100 \% 5$ minutes each) and embedded in Epon-Araldite. Polymerisation was carried out at $60^{\circ} \mathrm{C}$. Ultrathin sections were collected on copper grids to be contrasted with lead citrate and uranyl acetate and analysed and photographed under a Philips TEM.

\section{Results}

In A. mellifera, the ovaries are of meroistic polytrophic type. In this ovary type, once the mitotic proliferation phase of the secondary oogonia or cytoblast is over, one cell of the resulting clone differentiates into the oocyte while the other cells remain as nurse cells, or trophocytes. The ovarian follicles present in the vitellarium are divided into two interconnected chambers, the oocytic chamber that contains the oocyte and is located proximally to the nurse chamber that contains the trophocytes or nurse cells. All the cells of the nurse chamber are interconnected to each other and to the oocyte by cytoplasm bridges (Figures 1a-c). The nurse cells produce substances that are passed into the maturating oocyte.

\subsection{Light microscopy}

All the cells of the clone that constitute the nurse and oocyte cells undergo the $\mathrm{S}$ phase of the interphase that precedes meiosis. Therefore, even the nurse cells, right after the differentiation of the oocyte, possess 4C DNA. These cells present large and spherical nuclei showing numerous granules heavily stained by hematoxylin in a light stained nucleoplasm (Figure 1a), and little cytoplasm in relation to nucleus size. At this initial phase the average nurse cell area, measured in the sections is $1.569 \mu \mathrm{m}^{2}$ and the nucleus area is $460 \mu \mathrm{m}^{2}$. Soon after, these cells suffer a higher degree of polyploidisation, their nuclei becoming irregular and presenting a larger amount of chromatin granules (Figure 1b, c). The cytoplasm also increases (Figure 1b) and the cell sections present an area of 2,426 $\mu^{2}$ and a nucleus area of $600 \mu \mathrm{m}^{2}$, showing an increase in 1.5 and 1.3 times of cytoplasm and nucleus respectively. The growing phase of the nurse cells corresponds to the pre-vitellogenic stage of the oocyte, or before the yolk granules hematoxylin stained start to be seen in the oocyte. In vitellogenic oocytes, nurse cells are in regression; their nuclei are smaller and irregular, but they keep numerous hematoxylin granules stained in the nucleus. The cytoplasm has also diminished (Figure 1c).

The nucleus of the oocyte, commonly known as germinal vesicle, appears as a clear and spherical vesicle 
located at the anterior pole of the oocyte and containing few granules stained by hematoxylin (Figures. 1a and b). The nucleus of the oocyte has the same appearance during all the phases at which it is visible, except in the young oocytes, in which its envelope forms vesicles or bubbles, which originate the so called accessory nuclei that become disperse in the cytoplasm (Figures $1 \mathrm{~b}$ and $2 \mathrm{~b}$ ).

The follicular cells that surround the follicles are flat in the nurse chamber and do not suffer any changes during vitellogenesis. Around the oocyte, they are first cubic with apical and compact nuclei (Figures. 1a and 2a), and later prismatic with central nuclei (Figures $1 \mathrm{~b}$ and $2 \mathrm{~b}$ ) and finally very flat around the mature oocyte.

\subsection{Silver impregnation}

The impregnation by $\mathrm{AgNO}_{3}$ was used to evaluate the degree of nuclei activity in these cells, supposing that the amount of impregnated granules can be related to the RNAr synthesis performed in the nucleus.

The nuclei of the nurse cells show numerous impregnated nuclear regions and the intensity and number of regions impregnated by the silver varies according to the stage of oogenesis or oocyte development. Figures $2 \mathrm{a}$ and $2 \mathrm{~b}$ shows nurse cells with spherical nuclei and a few regions weakly impregnated, while the nuclei of the corresponding cells in Figures $2 \mathrm{~b}$ and $2 \mathrm{c}$ show irregular contours and numerous strongly impregnated granules mainly in $2 \mathrm{c}$. Figure $2 \mathrm{~b}$ corresponds to the maximum development of the nurse cells when they show the highest rate of material transfer towards the oocyte, while in Figure 2c, the nurse cells are already in a depleted stage, showing smaller and more condensed nuclei and hardly visible cytoplasm. The silver also impregnated granules within the germinal vesicle, even with a higher intensity than in the nurse cells nuclei. The impregnated material is eliminated by the vesicle, incorporated into the accessory nuclei that are dispersed through the peripheric cytoplasm of the oocyte tending to migrate towards its posterior pole (Figure $2 b$ ).

The follicular cells (Figures $2 \mathrm{a}$ and $2 \mathrm{~b}$ ) present nucleoli impregnated by silver, more intensely in vitellogenic oocytes (Figures 2b). In these cells, it is possible to observe some granules in the apical cytoplasm impregnated by silver.

\subsection{Transmission electron microscopy}

The Transmission Electron Microscopy shows the germinative vesicle of the oocyte presenting irregular margins and filled with electron-dense granules in a ground of median electron-density. Around the granules there are smaller and more electron-dense granules that seem to be detached from them (Figure 3a). Accessory nuclei can be observed scattered throughout the peripheral cytoplasm and although they mostly have nearly spherical shapes, some appear very irregular. Their envelope and content are similar to those of the germinal vesicle (Figure $3 b$ ).

In any stage, the nurse cells present large nuclear masses of thread-like eletrondense material disperse in the nucleoplasm and attached to the nuclear envelope (Figure 3c); as these masses increase in size and number,
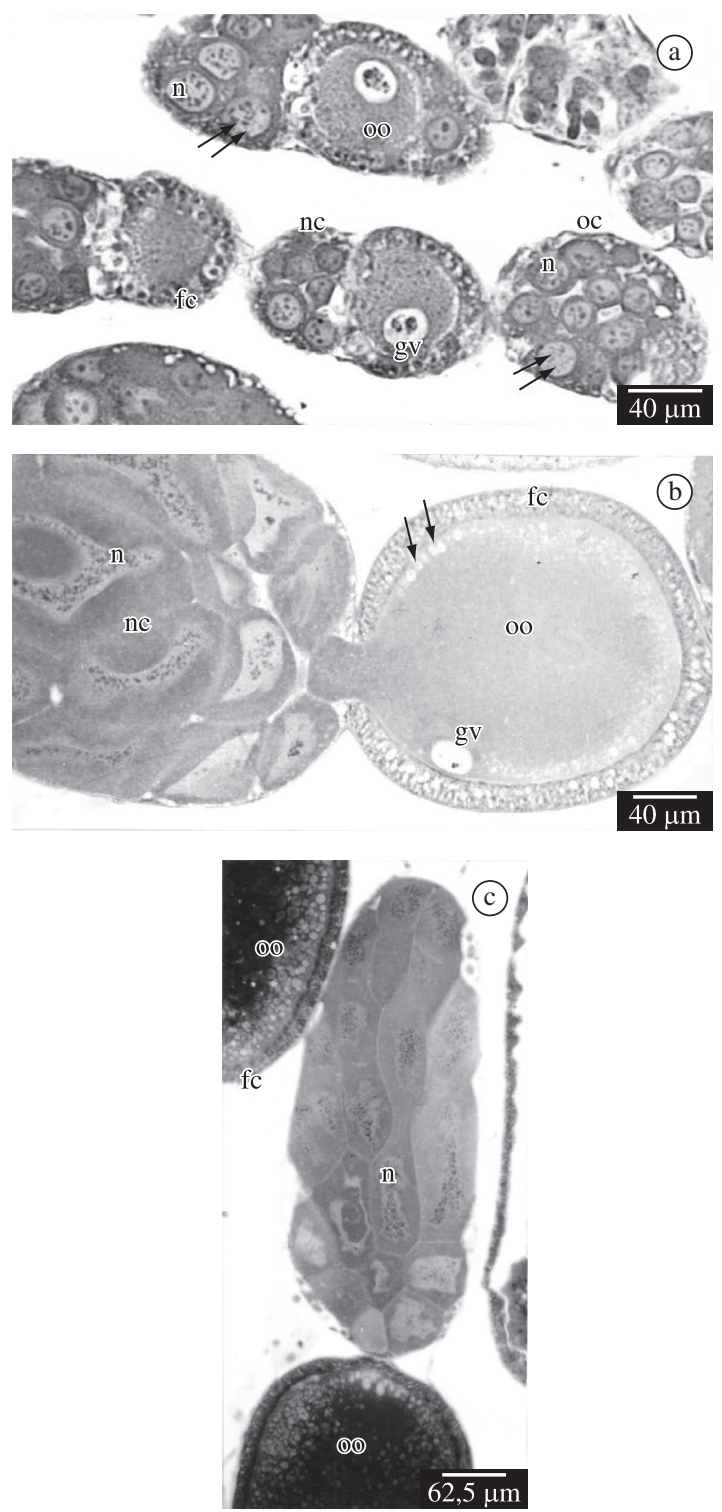

Figure 1. Follicles in A. mellifera ovary vitellarium. a) Young follicles at the beginning of the vitellarium. Note the nurse chamber (nc), larger than the oocytic chamber (oc), containing cells with spherical nuclei (n) and little cytoplasm. Note the oocyte (oo) germinal vesicle (gv) and the envelope of the follicular cells (fc). b) Note the increase in the size of the nurse cells (cn) and the irregular shape of their nuclei (n). The follicular cells (fc) surrounding the oocyte (oo) are cubic; the oocyte presents numerous accessory nuclei (arrows). c) Vitellogenic oocyte (oo) in which the nurse cells are at the beginning of the depleting process. Note the nuclei (n), more irregular and condensed.

the nuclei becomes irregular. The electron-dense material presents morphological features of a nucleolus. The nuclear envelope presents numerous pores and it is possible to observe the passage of material from the nucleoli-like structures into the cytoplasm through the pores (Figure 3c). This 

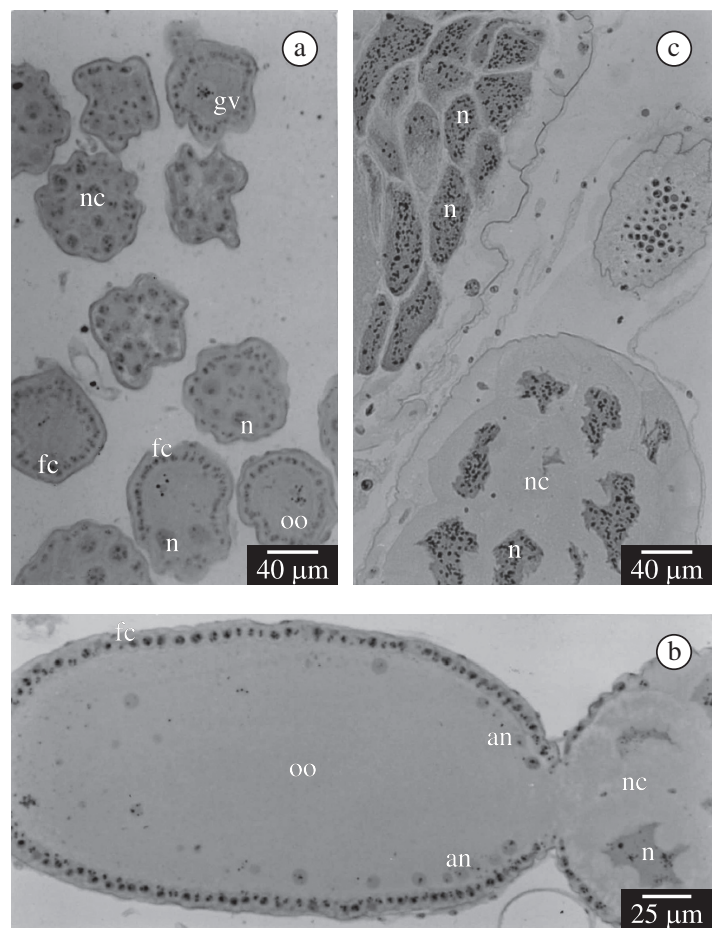

Figure 2. Silver impregnation. a) Nurse and oocytic chambers in transversal sections showing impregnated material in the nuclei (n) of the nurse cells (nc), follicular cells (fc), and in the germinal vesicle (gv) of the oocytes (oo). b) Silver staining of granules in the irregular nuclei (n) of the nurse cells (nc), in accessory nuclei (an) of the oocyte (oo), and in the follicular cells nuclei (fc). c) Nurse chambers (nc) in depleting process, showing a large amount of silver stained granules in the nuclei (n) of their cells.

material forms electron-dense deposits in the cytoplasm close to the nuclear envelope. Numerous mitochondria and isolated ribosomes can be observed in the cytoplasm of these cells.

The follicular cells also present large nucleolar masses, generally located centrally in the nucleus (Figure 3d).

\section{Discussion}

In insects with meroistic ovaries, the germinal vesicles of the oocyte are considered inactive. Thus, all the RNA and RNP present in the oocyte that will used at the beginning of embryogenesis would be produced in the nurse cells which are clones of the oocyte. Therefore, the function of these cells during oogenesis will be analogous to the loops of the lampbrush chromosomes present in vertebrate early oocytes. The presence of nurse cells, in meroistic ovaries of insects, corresponds to a strategy for the production of large amounts of nuclear products without the direct involvement of the oocyte's germinal vesicles. Since the nurse cells are clones of the oocyte, there are no differences in the products resulting from transcriptions in their nuclei and those that would occur in the nucleus of the oocyte. The
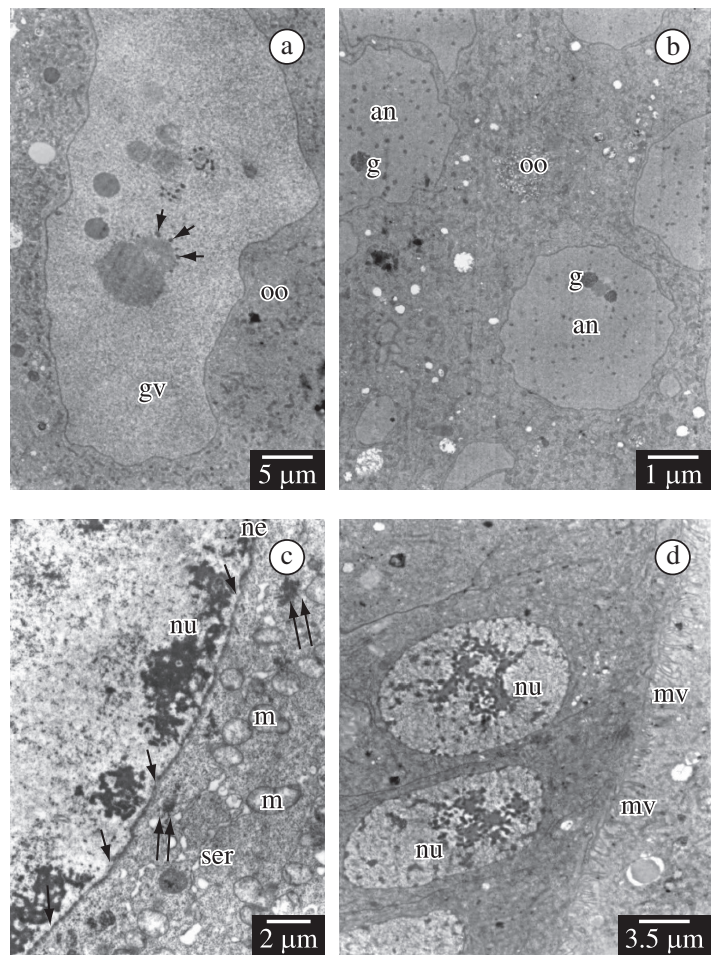

Figure 3. Transmission Electron Microscopy (TEM). a) Germinal vesicle (gv) showing the presence of electron dense granules (arrows) surrounding the chromatin masses. b) Accessory nuclei (an) in pre-vitellogenic oocytes (oo) showing granules (g) similar to germinal vesicle. c) Nurse cell of a young follicle showing peripheral nucleolar-like masses (nu); the nuclear envelope (ne) with numerous pores and the passage of material the cytoplasm (arrows) and electron dense material in the cytoplasm (double arrows). d) Follicular cells with large nucleoli (nu) in their nuclei. $\mathrm{m}=$ mitochondria; $\mathrm{mv}=$ microvilli; $\mathrm{ser}=$ smooth endoplasmic reticule.

products of the transcriptions on nurse cells are transferred to the oocyte throughout its maturation progress, and there stored, to be used during embryogenesis.

Through the technique of silver staining it was verified that the production of nucleolus-like masses in the ovarian cells, mainly in the nurse cells, increase with time, which might be related to the intensification of the transcription of specific regions of certain chromosomes that would produce long living mRNA and rRNA. In this case, the stained masses present in the nuclei are analogous to the micronucleoli present in the diplotenic nuclei of mammals' oocytes. The large amount of nucleolar-like material in nuclei of the nurse cells is due to the fact that the nuclei of these cells are polyploid, and very active in the production of RNA.

Although RNP is one of the main products transferred by the nurse cells into the oocyte, the $\mathrm{AgNO}_{3}$ did not impregnate its trajectory to the oocyte because it apparently only stains the recently transcribed nucleolar RNA and the nucleoli (Howell and Hsu, 1979). 
In young, pre-vitellogenic oocytes, granules present in the germinal vesicle are eliminated through bubbles from its envelope. The bubbles detached from the germinal vesicle will constitute structures known as accessory nuclei and have been reported in hymenopterans (Cruz-Landim and Caetano, 1981; Cruz-Landim, 1991). A positive reaction to Ag was verified in the granules inside the germinal vesicle and in the accessory nuclei of the oocyte, indicating their RNP nature. This result also indicates that the germinal vesicle is not as inactive as has been reported since it originates the accessory nuclei that transport nuclear material inside, to specific cytoplasm regions of the oocyte. Nevertheless, the material produced in the germinal vesicle, different from the material produced in the nurse cells, does not remain as part of the oocyte cytosol but is kept isolated inside the membranes of the accessory nuclei. It is known that RNA and RNP of maternal origin are unequally distributed in the cytoplasm of the oocytes, to regions with specific embryonic fates (Büning, 1994). Possibly, the material contained in the accessory nuclei must be kept from mixing with the other nuclear products coming from the nurse cells until a late stage of oogenesis or even embryogenesis.

The accessory nuclei migrate through the periphery of the oocyte towards the oocyte posterior pole. The fate and function of their content have not yet been clarified, but Cruz-Landim (1991) verified that in recently laid eggs, the membrane break and their contents are liberated into the posterior pole of the egg. Then, the enveloping membranes are organised as annular lamellae, an occurrence also reported by Staurengo da Cunha (1981). The accessory nuclei content become associated to a large amount of mitochondria that exist in this region. Although pole cells were not detected during the embryogenesis of A. mellifera, it is possible that the RNP contained in the accessory nuclei corresponds to the germplasm or oosome (Zissler and Sauder, 1977; Cruz-Landim, 1991).

At the end of vitellogenesis, the follicular cells secrete the viteline membrane and then the chorion of the oocyte (Margaritis, 1985). Thus, synthesis in these cells is intense during this stage. Therefore, the stronger impregnation of their nuclei by the Ag also indicates a higher nuclear activity. It is possible that these cells are polyploid as well.

In conclusion, the different cells that constitute the ovarian follicles present nuclear morphologies and Ag impregnation of nuclear material that indicate their degree of activity according with the functions they perform during oogenesis.
Acknowledegments - The authors are grateful to Fundação de Amparo à Pesquisa do Estado de São Paulo (FAPESP) for financial support.

\section{References}

BICUDO, HEMC., MADE-RAVAZZI, L. and NANYA, S., 1992. Simplified Ag-staining tecnique for nucleolar organizing regions and nucleoli. Revista Brasileira de Genética, vol. 15, no. 1 , p. 199-200.

BÜNING, J., 1994. The insect ovary: structure, previtellogenic growth and evolution. 5 ed. London: Chapmam \& Hall. 400 p.

CRUZ-LANDIM, C., 1991. Accessory nuclei in Hymenoptera oocytes and the germ plasm: a study of Melipona quadrifasciata anthidioides Lep. (Hymenoptera, Formicidae, Attinae). Atta sexdens rubropilosa forel (Hymenoptera, Formicidae, Attinae). Naturalia, vol. 16, p. 171-182.

CRUZ-LANDIM, C. and CAETANO, FH., 1981. The histochemistry and fine structure of the vitellarium in Atta (Formicidae, Myrmicinae). Revista Brasileira de Biologia = Brazilian Journal of Biology, vol. 41, no. 2, p. 363-70.

GOODPASTURE, C. and BLOOM, SE., 1975. Visualization of nucleolar organizer regions in mammalian chromosomes using silver staining. Chromosoma, vol. 53, no. 1, p. 37-50.

LISCHWE, MA., SMETANA, K., OLSON, MOJ. and BUSCH, H., 1979. Protein-C23 and protein-B23 are the major nucleolar silver staining proteins. Life Science, vol. 25, p. 701-708.

LISCHWE, MA., RICHARDS, RL., BUSCH, RK. and BUSCH, H., 1981. Localization of phosphoprotein C23 to nucleolar structures and to the nucleolus organizer regions. Experimental Cell Research, vol. 136, no. 1, p. 101-109.

MARGARITIS, LH., 1985. Structure and physiology of the egg shell. In GILBERT, LI. (Ed.). Comprehensive insect physiology, biochemistry and pharmacology. Oxford: Pergamon Press. p. 30-82. (vol. 1)

SCHWARZACHER, HC., MIKELSAAR, AV. and SCHNEDL, W., 1978. Nature of Ag-staining of nucleolus organizer regions electron microscopic and light microscopic studies on human cells in interphase, mitosis, and meiosis. Cytogenetics and Cell Genetics, vol. 20, no. 1, p. 24-39.

STAURENGO da CUNHA, MA., 1981. Números de células nos cistos ovarianos de Scaptotrigona postica Latr. (Hymenoptera, Apidae). Revista Peruana de Entomologia, vol. 24, no. 1, p. 67-70.

HOWELL, WM. and HSU, TC., 1979. Chromosome core structure revealed by silver staining. Chromosoma, vol. 73, no. 1, p. 61-66.

ZISSLER, D. and SAUDER, K., 1977. The cytoplasmic architecture of the egg cell of Smittia spe. (Diptera, Chironomidae). II. Periplasm and yolk endoplasm. Roux's Archives of Developmental Biology, vol. 183 , no. 1 , p. 233-248. 
